\title{
GUILLAIN-BARRE SYNDROME AS A DIFFERENTIAL DIAGNOSIS OF LOW BACK PAIN SYNDROME
}

\author{
SIINDROME DE GUILLAIN-BARRÉ COMO DIAGNÓSTICO DIFERENCIAL DE SÍNDROME \\ DE DOR LOMBAR

\section{EL SÍNDROME DE GUILLAIN-BARRÉ COMO DIAGNÓSTICO DIFERENCIAL DEL SÍNDROME DE DOLOR LUMBAR}

José María Jiménez Avila', Alberto Aceves Pérez', Arelhi Catalina González Cisneros², José luis Guzmán Guzmán ${ }^{3}$

1 Orthopedic Service of the Centro Médico Nacional de Occidente, IMSS in Guadalajara, Jalisco, Mexico.

2. Tecnológico de Monterrey. Campus Guadalajara, Mexico.

3. Neurology Service of the Centro Médico Nacional de Occidente, IMSS in Guadalajara, Jalisco, Mexico.

\begin{abstract}
Peripheral neuropathies are diseases of the lower motor neurons of the spinal cord and brainstem it can often mimic symptoms associated with the injuries of compressive radiculopathy. They are manifested by tingling, coldness, numbness, burning, pain, hypersensitivity, weakness, atrophy, postural hypotension, impotence, anhidrosis, and urinary incontinence. Therefore, it is important in the diagnostic strategy to keep in mind this type of pathology, especially when it comes to patients already in the 6th decade of life.
\end{abstract}

Keywords: Polyneuropathies; Polyradiculoneuropathy; Guillain-Barre syndrome; Low back pain.

\begin{abstract}
RESUMO
As neuropatias periféricas são doenças dos neurônios motores inferiores da medula espinal e do tronco encefálico, cujos sintomas podem mimetizar, muitas vezes, lesões associadas à radiculopatia de origem compressiva. Manifestam-se por formigamento, frigidez, dormência, queimação, dor, hipersensibilidade, fraqueza, atrofias, hipotensão postural, impotência, anidrose e incontinência urinária. Portanto, é importante na estratégia de diagnóstico ter em mente esse tipo de patologia, principalmente quando se trata de doentes já na sexta década de vida.
\end{abstract}

Descritores: Polineuropatias; Polirradiculoneuropatia; Síndrome de Guillain-Barré; Dor lombar.

\section{RESUMEN}

Las neuropatías periféricas son trastornos de las neuronas motoras inferiores de la médula y del tallo encefálico, cuya sintomatología puede semejar muchas veces lesiones asociadas a una radiculopatía de origen compresiva. Se manifiestan por sensación de hormigueo, frialdad, adormecimiento, quemadura, dolor, hipersensibilidad, debilidad, atrofias, hipotensión arterial postural, impotencia, anhidrosis e incontinencia de esfínteres. Por lo tanto, es importante en la estrategia diagnóstica tener presente este tipo de patologías principalmente cuando se trata de pacientes que pasan la $6^{a}$ década de la vida.

Descriptores: Polineuropatías; Polirradiculoneuropatía; Síndrome de Guillain-Barré; Dolor de la región lumbar.

\section{INTRODUCTION}

Peripheral neuropathies are persistent disorders of the lower motor neurons of the spinal cord and the brain stem, of the primary sensory neurons, or of the peripheral autonomic neurons, with clinical electrographic and morphological manifestations ${ }^{1}$ of an inflammatory or degenerative nature, that are manifested clinically by a tingling sensation, coldness, numbness, burning, pain, hypersensitivity, weakness, atrophy, postural hypotension, impotence, anhidrosis, and urinary incontinence..$^{2-4}$

The estimated prevalence of peripheral neuropathies is around $2 \%$ in the general population and in adults over 55 years of age can reach as high as $8 \%,{ }^{1}$ ranking them among the most common neurological changes. Their severity ranges from mild sensory abnormalities to fulminant life-threatening paralytic disorders and their differential diagnosis is at risk because the illnesses that they produce are so numerous. Despite efforts to identify them, no adequate explanation for these disorders is found in $24 \%$ of the patients studied in specialized centers. ${ }^{2,4-6}$

\section{Classification}

Peripheral neuropathies can be classified into 5 large groups (Table 1):

By distribution: Mononeuropathies that compromise only one nerve trunk; multiple mononeuropathies with the successive compromise of several nerve trunks, and distal polyneuropathies with diffuse and symmetrical compromise of the four limbs.

By dominant manifestations: Motor, sensory, autonomic, and mixed.

By duration: may be acute (evolving over 3 weeks) - Guillain-Barré syndrome, diphtheritic polyneuropathy, porphyric polyneuropathy, neuralgic amyotrophy, polyneuropathy of the connective tissue; chronic (evolving over more than a month - diabetic neuropathy, amyloid neuropathy, nutritional or toxic; hereditary; and recurrent (with partial or complete recovery between recurrences).

By pathological characteristics: There can be axonopathies characterized by morphological abnormalities in the proximal or distal segments of the axons and myelinopathies characterized by the loss 
of myelin, accompanied by myelinophagia by the macrophages. ${ }^{7}$

By etiology and the association with illnesses that may be: infectious - leprosy, herpes, and viral (Epstein-Barr, cytomegalovirus, and influenza); ischemic: diabetes, atherosclerosis, vasculitis, collagenopathies; mechanical - from compression, elongation, or section; and various - amyloidosis, tumors, Bell's palsy, mucopolysaccharidosis, medications (isoniazid, metronidazole, ethambutol, nitrofurantoin, colistin, dapsone, vincristine, cisplatin, taxol, vinblastine, doxorubicin, amiodarone, thalidomide, colchicine, gold salts, penicillamine, chloroquine, cyclosporine, phenytoin, disulfiram, cimetidine).

\section{Etiology}

Table 1. In some axonopathies and myelinopathies, the myelin sheaths and axons may be simultaneously affected.

\begin{tabular}{|c|c|c|}
\hline Axonopathies & Myelinopathies & Other types \\
\hline $\begin{array}{l}\text { Of genetic origin } \\
\text { - Fibular muscular } \\
\text { atrophy } \\
\text { - Giant axonal neuropathy } \\
\text { - Ataxia telangiectasia } \\
\text { - Axonopathy of } \\
\text { polyglucosan bodies } \\
\text { - Fabry's disease } \\
\text { - Tangier's disease } \\
\text { - Familial dysautonomia } \\
\text { - Friedreich's ataxia } \\
\text { - Neuroaxonal dystrophy } \\
\text { Agenesis of the corpus } \\
\text { callosum } \\
\text { Acquired } \\
\text { 1. Exogenous toxins and } \\
\text { medications } \\
\text { a) Metals } \\
\text { b) Solvents } \\
\text { c) Foods } \\
\text { d) Invertebrate toxins } \\
\text { e) Medications } \\
\text { f) Other } \\
\text { 2. Metabolic disorders } \\
\text { Diabetes, kidney failure, } \\
\text { liver failure, porphyria, } \\
\text { hypothyroidism. } \\
\text { 3. Deficiencies } \\
\text { Thiamine, } \\
\text { hydroxocobalamin, } \\
\text { folate, pyridoxine, } \\
\text { niacin, riboflavin } \\
\text { 4. Cancers }\end{array}$ & \begin{tabular}{|l|} 
Of genetic origin \\
- Charcot-Marie-Tooth \\
- Ryndrome. \\
Soussy-Levy \\
Sevy \\
- Refsum disease \\
- Adrenoleucodistrofia \\
- Krabbe disease \\
- Pelizaeus \\
Merzbacher disease \\
Acquired \\
1. Ideopathic and \\
infectious \\
- Acute (Guillain- \\
Barré Syndrome) \\
- Chronic \\
- Recurrent \\
- Branchial \\
- Post vaccination \\
- Childish \\
2. Toxic \\
- Diphteria \\
- Lead \\
- Hexachlorophene \\
and cyanide \\
3. Metabolic \\
- Diabetes \\
- Dysproteinemias
\end{tabular} & $\begin{array}{l}\text { Infectious } \\
\text { - Leprosy } \\
\text { - Herpes } \\
\text { - Epstein-Barr, } \\
\text { - Influenza } \\
\text { Ischemic } \\
\text { - Diabetes } \\
\text { - Vasculopahies } \\
\text { - Atherosclerosis } \\
\text { Mechanical } \\
\text { - Compression } \\
\text { - Elongation } \\
\text { - Section. } \\
\text { Several } \\
\text { - Amiloidosis } \\
\text { - Mucopolysacchari- } \\
\text { - Tosis } \\
\text { - Electrical injuries } \\
\text { - Peri neuritis. }\end{array}$ \\
\hline
\end{tabular}

\section{Clinical}

The clinical picture can be very broad, with features ranging from asymptomatic patients, to mildly symptomatic patients, to patients with the typical advanced condition. The typical picture of polyneuropathy is observed in acquired toxic or metabolic neurological processes.

The first symptoms are usually sensory, with stinging, tingling, burning or dysesthesia in the heels, the toes, and the soles of the feet, usually evolving symmetrically with increasing intensity in a distal direction.

As the disease progresses, the dysesthesia spreads to the lower part of the legs, accompanied by weakness in the toes, feet, and legs. The Achilles reflex disappears and the sensory deficit moves progressively in a centripetal direction in the shape of a "sock" ., 1,8,8

Then the patellar reflex disappears and when the sensory deficit reaches the upper part of the shin, dysesthesia usually begins to affect the toe, with loss of feeling distributed in a "glove" or "sock" pattern.

The degree of spontaneous pain is variable. It can compromise gait through proprioceptive changes. When the sensory disturbance reaches the elbows and the mid-thigh, there is usually a zone of hypoesthesia in the lower abdomen that later continues to grow and spread. Patients often cannot remain standing or walk, or grasp objects with their hands. The motor deficit is also usually gradual, distal, and symmetrical.

Polyneuropathies show a significant degree of diversity due to their extreme variability in terms of speed of evolution, severity, mixture of sensory and motor changes, and presence or absence of certain symptoms. ${ }^{8-11}$

\section{Case History}

Female patient, 63 years of age, originally from Ruiz, Nayarit, and living in Guadalajara, Jalisco, Roman Catholic, housewife, with significant medical history: late father died of an acute myocardial infarction; mother living and with arterial hypertension; no knowledge of her childhood diseases; no known allergies; transfusions; 4 surgical events - at 18 , open reduction and internal fixation secondary to fracture of right elbow, spine surgery more than 20 years ago secondary to L5-S1 disc hernia, tubal ligation, Caesarian section; chronic, intermittent low back pain. Tetanus immunization 4 weeks before, menarche at 12 years of age, 4 pregnancies, 3 natural and 1 Caesarian delivery.

Her condition began on February 21, 2012 with intermittent pain in the lumbar segment, which evolved progressively and chronically. She also had hypoesthesias, pareses, and paresthesias, reduced muscular strength in the lower limbs. She was evaluated and treated with analgesics for her symptoms with no improvement.

On examination, the patient was found to be conscious, oriented in time, space, and place, her apparent age aligned with her chronological age, with facial expressions of pain, neurological examination showed cranial nerves preserved, range of movement at the level of the cervical spine unchanged, but limited by pain at the thoracolumbar level, lower limbs with muscle strength at level IV on the Daniel's scale, bilateral hypoesthesia at the S1 and L5 level, patellar and Achilles reflexes of reduced intensity, Babinski negative sign, and negative Lasègue's sign.

Two days following her admission, a new physical exam reported reduced strength of the right biceps 4, left biceps 4, right triceps 4, left triceps 4, right palmar grasp 3, left palmar grasp 3, lower limbs proximal right 1, lower limbs proximal left 1, lower limbs distal right 1, lower limbs distal left 1 on the Daniel's scale; without pyramidal liberation data.

At the sensory level, hypoesthesia of the lower limbs, though not adequately defined, and cerebellar signs were observed. Gait could not be evaluated due to the weakness of the muscles.

In the paraclinical exams of 02/27/2012, flow cytometry results were leukocytes 9.9, hemoglobin $15.2 \mathrm{~g} / \mathrm{dL}$, hematocrit $46.3 \%$, platelets 236.000, serum glucose $99 \mathrm{mg} / \mathrm{dL}$, urea 36 , creatinine $0.4 \mathrm{mg} / \mathrm{dL}$.

$\mathrm{AP}$ and lateral projections of the lumbosacral spine with degenerative arthritic changes, highlighting a syndesmophytic formation on the upper platform of L5. There was no evidence of instability, displacement, or involvement of the spinal canal. (Figure 1)

Magnetic resonance of the thoracolumbar spine-February 28, 2012

Dehydration of intervertebral discs of L2/L3, L3/L4, and L4/L5 without discal protrusions or signs of compressive radiculopathy. (Figure 2).

Facet arthrosis of L3/L4, L4/L5, or L5/S1. The spinal cord reaches the T12/L1 level without evidence of lesions in the interior of the dural sac. (Figure 3).

Conclusion: Initial signs of degenerative discarthrosis and facet arthrosis without stenosis of the canal or spinal cord injury.

\section{Electromyography, February 29, 2012}

Abnormal with signs of lumbar radiculopathy at levels L3, L4, L5, and $\mathrm{S} 1$, predominantly on the left side; data indicating moderate to severe predominantly axonal sensory-motor polyneuropathy.

\section{CSF cytochemistry, March 6, 2012}

Very scarce erythrocytes, $99 \%$ normal, $1 \%$ crenate, yeasts negative, leukocytes were not observed, glucose $62 \mathrm{mg} / \mathrm{dl}$, serum glucose $99 \mathrm{mg} / \mathrm{dl}$, proteins 399, slightly turbid appearance.

\section{CT, February 24, 2012}

The integrity of the vertebral bodies was observed, without any bone involvement in the spinal canal, but with arthritic changes in the 


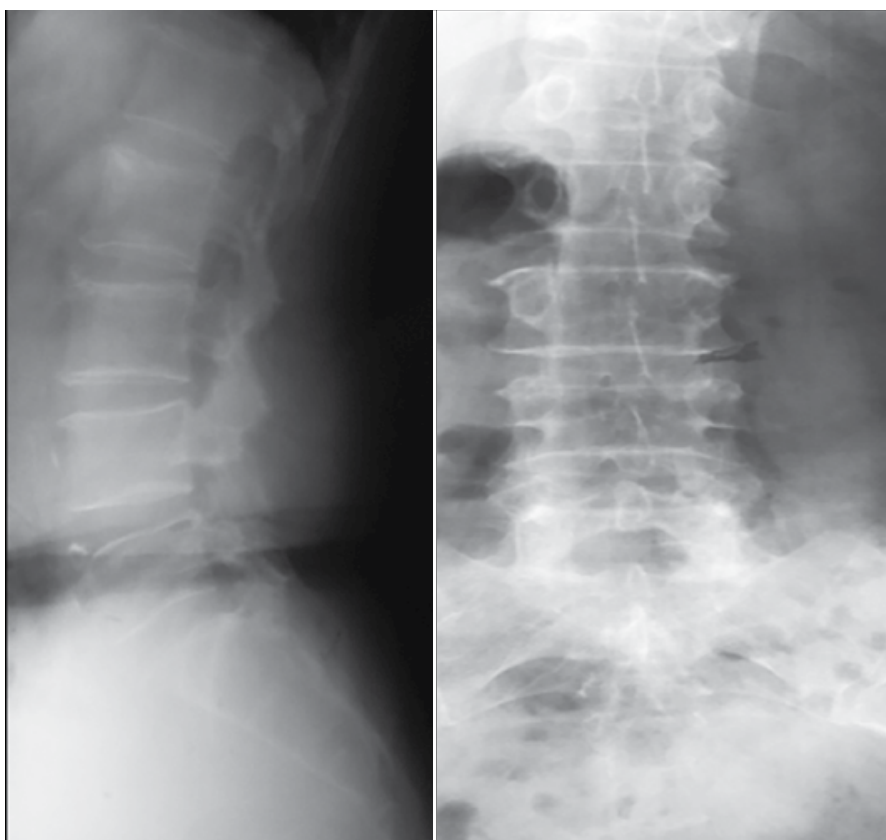

Figure 1. AP and lateral projections of the lumbosacral spine, with degenerative arthritic changes.

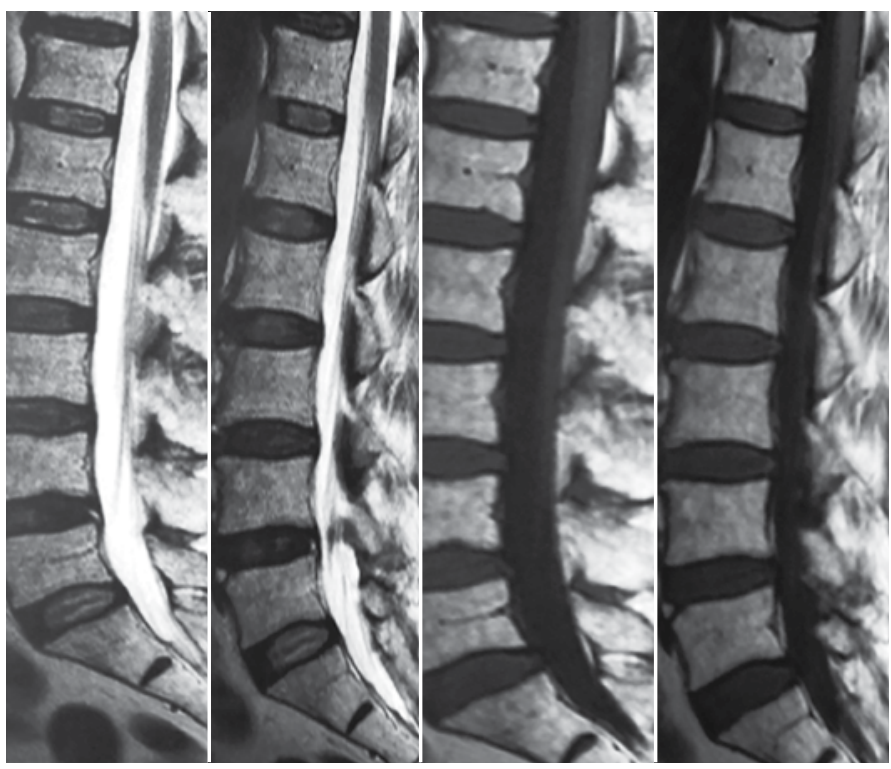

Figure 2. Lumbar MRI, in T1 and T2 phases, without compromise to the spinal canal, with dehydration of the $L 2, L 3$, and $L 4$ discs.
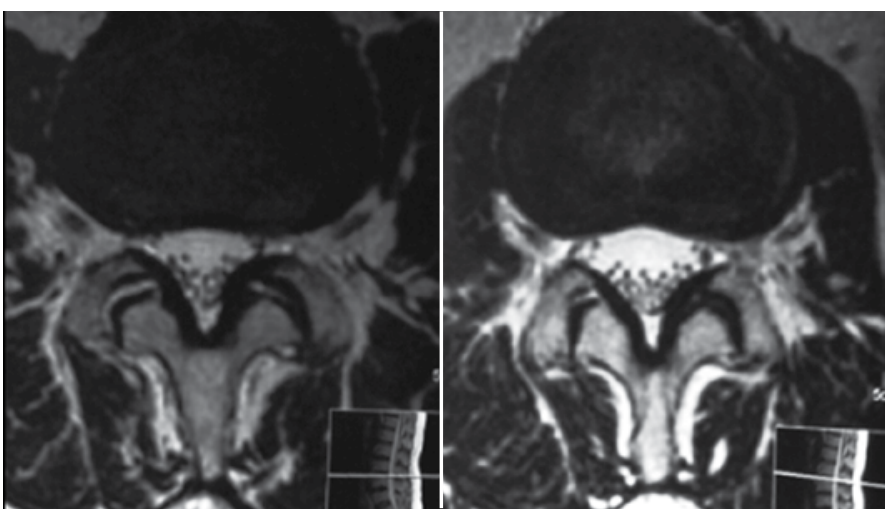

Figure 3. MRI in T1 and T2 phases with evidence of bilateral facet hypertrophy, without involvement of the L3/L4 nerve roots. upper and lower platforms of the lumbar bodies (Figure 4).

The patient presented clinical, cytological, and electromyographical criteria of acute inflammatory demyelinating polyneuropathy, leading to a diagnosis of Hughes IV Guillain-Barré syndrome. Specific treatment initiated, based on immunoglobulin, calculated on an ideal weight of $65 \mathrm{~kg}$, corresponding to $26 \mathrm{~g}$ daily for 5 days. Immunoglobulin $5 \mathrm{~g} / 100 \mathrm{ml}-5.2$ vials daily $-21.6 \mathrm{ml} / \mathrm{hr}$, immunoglobulin $6 \mathrm{~g} / 120 \mathrm{ml}-4.3$ vials daily $-21.6 \mathrm{mg} / \mathrm{hr}$, and immunoglobulin $6 \mathrm{gr} / 4.3$ vials daily- $36.2 \mathrm{ml} / \mathrm{hr}$.

The patient presented an improvement of symptoms 4 days following the onset of the administration of immunoglobulin, with improved mobility and sensitivity in the legs. There was no evidence of secondary effects from the treatment.

\section{CONCLUSIONS}

Low back pain syndrome has multiple differential diagnoses, among which one of the least suspected in the Landry-Guillain-BarréStrohl syndrome (GBS), a demyelinating polyradiculoneuropathy characterized by muscular weakness and areflexia, which has an acute evolution (up to 4 weeks) and may be recurrent.

The reason for suspicion of this disease in this patient was that the clinical manifestations, the findings of the physical examination,

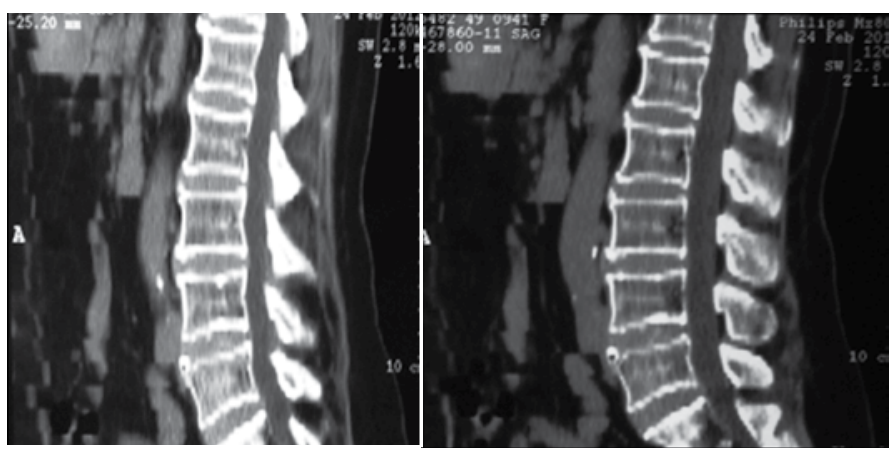

Figure 4. Integrity of the vertebral bodies with arthritic changes.

and the symptoms were not consistent with the studies consulted. A systematic review of the existing literature on the low back pain syndrome was conducted and we found demyelinating-type peripheral neuropathies, such as GBS, as non-organic causes.

Epidemiologically, it is a syndrome that occurs worldwide, affecting around 1 in 100,000 people in all age groups. It is not hereditary.

Most patients report prior bacterial or viral respiratory or gastrointestinal infections, or vaccinations prior to the onset of neurological symptoms.

In this pathology, the cerebrospinal fluid has an increase in proteins, while the cellularity is normal (albuminocytological disassociation).

Total recovery of the patient requires specific management that may include immunotherapy using intravenous immunoglobulin $\mathrm{G}$, human immunoglobulin $\mathrm{G} 4$ in doses of $400 \mathrm{mg} / \mathrm{kg} /$ day for 4 days or the use of plasmapheresis, which was the first type of treatment that showed benefits in the management of patients with this syndrome.

With this treatment regimen, the number of days of respiratory support and the total hospitalization time, both in children and adults, are reduced. The recommendation calls for replacement of $5 \%$ of the body weight or $50 \mathrm{mg} / \mathrm{kg} /$ day of plasma for 7 to 10 days.

Demyelinating polyradiculoneuropathy is a pathology that should be considered in the differential diagnosis of low back pain syndrome.

All the authors declare that there are no conflicts of interest regarding this article. 
CONTRIBUTIONS OF THE AUTHORS: Each author made significant individual contributions to the development of this manuscript. RT wrote the abstract, provided the translations, wrote the Materials and Methods section, and contributed to the Discussion section. RM built the statistical tables, wrote the Results section, and contributed to the Discussion section. EB prepared the Conclusions section based on the Results Section and contributed to the Discussion section.

\section{REFERENCES}

1. Di Perri C, Bahri MA, Amico E, Thibaut A, Heine L, Antonopoulos G, et al. Neural correlates of consciousness in patients who have emerged from a minimally conscious state: a cross-sectional multimodal imaging study. Lancet Neurol. 2016; pii: S1474-4422(16)00111-3.

2. Castañeda-Fernández JA, del Corral-Garcia J. Neuropatías periféricas. Medisan. 2003;7(4):35-41.

3. Kraychete DC, Sakata RK. Neuropatías periféricas dolorosas. Rev Bras Anestesiol. 2011:61(5):641-58.

4. Oterino A: Neuropatías periféricas. Actualización. JANO. 6-12, 2008, no 1.699. Disponível em: http://www.jano.es/ficheros/sumarios/1/0/1699/20/00200024-LR.pdf

5. Monroy-Guerrero J, Núñez-Orozco L. Síndrome de Landry-Guillain-Barre-Strohl. Una actualización. Rev Mex Neuroci 2005;6(3):271-82.

6. Khan F, Pallant JF, Amatya B, Ng L, Gorelik A, Brand C. Outcomes of high-and low-intensity rehabilitation programme for persons in chronic phase after Guillain-Barré syndrome: a randomized controlled trial. J Rehabil Med. 2011:43(7):638-46

7. Sejvar JJ, Baughman AL, Wise M, Morgan OW. Population incidence of Guillain-Barré syndrome: a systematic review and meta-analysis. Neuroepidemiology. 2011;36(2):123-33.

8. Soledad-Gamarra GN, Rosciani FD, Sosa F. Síndrome de Guillain Barré. Rev Posgrado de la Vía Catedra Med. 2010;(199):15-8.

9. Barzallo C, Vallejo M. Una nueva definición del dolor neuropático y un nuevo enfoque para guiar su diagnóstico. Rev Iberoamer Dolor. 2008;3(1): 52-6.

10. Alexander M, Prabhakar AT, Aaron S, Thomas M, Mathew V, Patil AK. Utility of neurophysiological criteria in Guillain Barre syndrome: subtype spectrum from a tertiary referral hospital in India. Neurol India. 2011;59(5):722-6.

11. Walgaard $C$, Lingsma HF, Ruts $L$, van Doorn $P A$, Steyerberg EW, Jacobs $B C$. Early recognition of poor prognosis in Guillain-Barre syndrome. Neurology. 2011;76(11):968-75. 